\title{
First record and DNA barcodes of the invasive blue-coloured spiny-cheek crayfish Faxonius limosus (Rafinesque, 1817) (Decapoda: Cambaridae)
}

\author{
Rafał Maciaszek ${ }^{1, *}$, Maciej Bonk ${ }^{2}$, Witold Sosnowski ${ }^{3}$ and Aleksandra Jabłońska ${ }^{4}$ \\ ${ }^{1}$ Department of Animal Genetics and Conservation, Institute of Animal Sciences, Warsaw University of Life Sciences, ul. Ciszewskiego 8, \\ 02-786 Warsaw, Poland \\ ${ }^{2}$ Institute of Nature Conservation, Polish Academy of Sciences, al. Adama Mickiewicza 33, 31-120 Kraków, Poland \\ ${ }^{3}$ Laboratory of Marine Organisms Reproduction, Faculty of Food Sciences and Fisheries, West Pomeranian University of Technology, \\ ul. Kazimierza Królewicza 4, 70-001 Szczecin, Poland \\ ${ }^{4}$ Department of Invertebrate Zoology and Hydrobiology, University of Lodz, ul. Banacha 12/16, 90-237 Łodź, Poland
}

Received: 14 February 2020 / Accepted: 8 April 2020

\begin{abstract}
This contribution presents first record of a blue colour morph of spiny-cheek crayfish, Faxonius limosus (Rafinesque, 1817). Two unusually coloured individuals were caught in Poland, in two different locations, separated from each other by approximately $500 \mathrm{~km}$ and belonging to different river catchments (Oder and Vistula), within the range of the species occurrence in Europe. Taxonomic identification of collected crayfish has been confirmed by the standard DNA barcoding procedure. Although blue coloured forms of crayfish have been previously described within the Cambaridae family, collected individuals are the first records of blue colouration within F. limosus. It is recommended to supplement identification keys with a new colour form of the species, which, while characteristic dark red bands are not clear, may cause mistakes in recognition of exotic, aquarium as well as native species.
\end{abstract}

Keywords: Astacidae / alien species / ornamental pet trade / inland waters / Central Europe

\begin{abstract}
Résumé - Premier signalement et code-barres ADN de l'écrevisse américaine Faxonius limosus (Rafinesque, 1817) (Decapoda: Cambaridae) de couleur bleue, espèce envahissante. Cette contribution présente le premier signalement d'une forme de couleur bleue de l'écrevisse américaine, Faxonius limosus (Rafinesque, 1817). Deux individus de couleur inhabituelle ont été capturés en Pologne, dans deux endroits différents, séparés l'un de l'autre d'environ $500 \mathrm{~km}$ et appartenant à des bassins versants différents (Oder et Vistule), dans l'aire de répartition de l'espèce en Europe. L'identification taxonomique des écrevisses collectées a été confirmée par la procédure standard de codage à barres de l'ADN. Bien que des formes d'écrevisses de couleur bleue aient déjà été décrites au sein de la famille des Cambaridés, les individus collectés sont les premiers à présenter une coloration bleue chez $F$. limosus. Il est recommandé de compléter les clés d'identification par une nouvelle forme de couleur de l'espèce, qui, alors que les bandes rouge foncé caractéristiques ne sont pas claires, peut entraîner des erreurs dans la reconnaissance des espèces exotiques, d'aquarium et indigènes.
\end{abstract}

Mots clés : Astacidae / espèces exotiques / commerce d'animaux / eaux intérieures / Europe centrale

Crayfish are crustaceans valued in aquaculture, where they are bred for food (Holdich, 1993). They are characterized by widespread variety of colour which encourages their participation at global exhibitions and ornamental pet competitions (Chucholl and Wendler, 2017). In both cases, the most commonly used are representatives of Cambaridae family (Holdich, 1993; Souty-Grosset et al., 2016). On the other hand, their high resistance to adverse environmental conditions and

\footnotetext{
*Corresponding author: rafal_maciaszek@sggw.pl
}

relatively low breeding requirements have contributed to uncontrolled expansion of their populations around the world due to escaping from the aquaculture or intentional introductions (Chucholl, 2013; Patoka et al., 2014; Oficialdegui et al., 2019; Maciaszek et al., 2019).

The spiny-cheek crayfish, Faxonius limosus (Rafinesque, 1817), previously known as Orconectes limosus (Crandall and De Grave, 2017), is a representative of the Cambaridae family, naturally occurring in freshwaters of north-eastern USA (Souty-Grosset et al., 2006). It was intentionally introduced in 
Europe into a breeding pond in Barnówko (nowadays NorthWestern Poland) in the 1890s. From that locality the species entered open waters and began its expansion which was additionally supported by subsequent introductions (Filipová et al., 2011). The justification for the release of F. limosus in European waters was its resistance to crayfish plague caused by Aphanomyces astaci (Schikora, 1906), a parasitic water mould causing crayfish diseases that drastically reduced the population of species native to Europe (such as the one of noble crayfish Astacus astacus (Linnaeus, 1758) (Svoboda et al., 2017; Śmietana et al., 2018). Unfortunately, the new species proved to be of a smaller size and less palatable than the native species therefore it was considered inferior from a commercial aspect (Nolfi, 1980). Although, as to the latter, newer studies are not necessarily consistent (Krzywosz, 1999; Stanek et al., 2010).

F. limosus is currently found in most of Central and Western European freshwaters (Kouba et al., 2014; Seprös et al., 2018), where it prevents effective reintroduction of native crayfish species due to being a potential plague vector and a competitive invasive species. It also contributes to acquired aquatic ecosystems degradation process (Pârvulescu et al., 2009; Manenti et al., 2019). Despite imposed ban based on the species being listed among invasive in Poland, F. limosus is regularly sold on zoological and aquatic shows and markets as a crustacean proposed for private ponds (Śmietana et al., 2018). F. limosus can be also found in aquaculture ponds, where it gets to from adjacent waterbodies (Patoka et al., 2014; Śmietana et al., 2018). On a small scale this species is also observed in the so-called aquatic biotope sector due to being the most common crayfish in Polish waters (Śmietana et al., 2018), where F. limosus is introduced as representative of crustaceans.

Fortunately, F.limosus is a species relatively easy to determine thanks to the presence of characteristic multiple spines located on hepatic (cheek) region of carapace, not occurring in other representatives of the family Cambaridae observed in European waters (Svecker et al., 2019). This typically brown or grey-coloured crayfish can be also distinguished from native crayfish by the presence of dark red bands on the abdomen segments, orange claw tips and simultaneously the lack of rostral cresta median (Füreder and Machino, 2002; Souty-Grosset et al., 2006; Śmietana et al., 2018). However, none of the recognisable features seem to have such a significance as those dark red bands. They seem to be the most notable feature often used for marking by anglers, aquarists or veterinary inspectors. Difficulties in assessing all the other characteristics could contribute to erroneous identification, which then could result in further spread of unwanted, invasive crayfish in Europe.

In this study, we provide the first report on the occurrence of the blue coloured Faxonius limosus.

The total of 380 crayfish were collected in two sampling sites (Fig. 1). Among gathered specimens two were characterized by the blue colouration of the carapace and terga (Fig. 2).

First of untypically coloured specimens was found on May 1, 2018. Observation of colour durability of this particular individual was carried on for a year in aquarium conditions. It was collected from Dziewoklicz city beach, situated in southern part of Szczecin, north-west Poland $\left(53.3788^{\circ} \mathrm{N}\right.$,

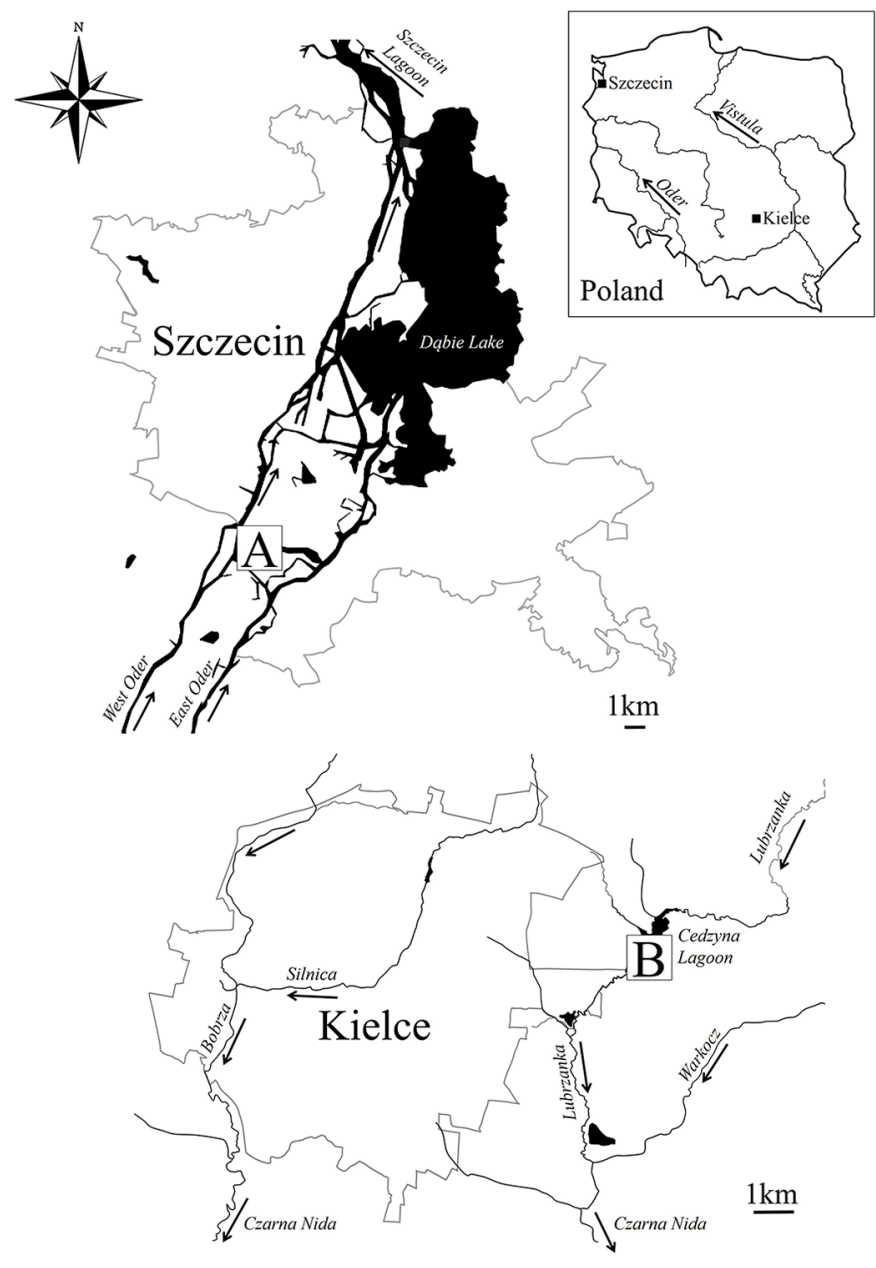

Fig. 1. Localisation of sampling sites in Szczecin, city beach of Dziewoklicz (A) and Cedzyna Lagoon near Kielce (B).

$14.5379^{\circ} \mathrm{E}$ ) located on the Oder River, ca. $9.5 \mathrm{~km}$ from the Poland-Germany border. The beach is a valued place of rest and recreation among the local community, and throughout its entire area, it is included in the buffer zone of the Landscape Park "Lower Oder Valley" and Natura 2000 project. Additional inspections at that site were carried out in May 2018 and 2019, however, no more blue specimens were found.

The second individual was observed on October 14, 2019 during regular catches of F. limosus crayfish conducted from November the 10th to October the 30th, 2019 in the Cedzyna Lagoon near Kielce (Central and Eastern Poland) $\left(50.8770^{\circ} \mathrm{N}\right.$, $\left.20.7346^{\circ} \mathrm{E}\right)$.

Due to its natural values, the entire reservoir is included in Podkieleckie Protected Landscape Area. It is also used by local hydroelectric plant as well as provides recreational activities.

Both studied crayfish were caught using the hydrobiological hand net. After being transported to the laboratory, collected individuals were identified, measured and photographed. For an observation of the colour stability they were placed into an aerated aquaria with water set to room temperature for at least 3 weeks. At the time specimens were fed with food rich in astaxanthin.

Both specimens were barcoded with the use of the cytochrome C oxidase subunit I (COI) marker. DNA was 


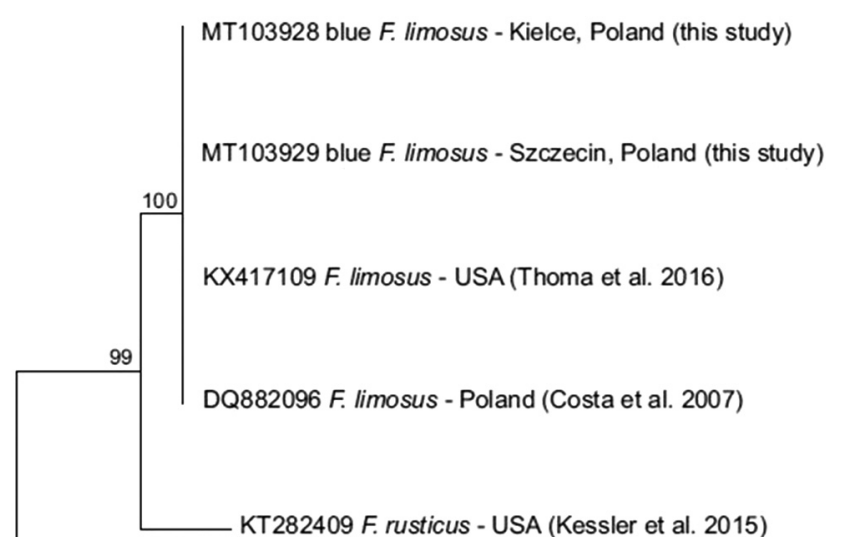

KT282409 F. rusticus - USA (Kessler et al. 2015)

MG872956 F. barrenensis - USA (Fetzner and Taylor 2018)

Fig. 2. Faxonius limosus. A. Blue morph (female)-Szczecin; B. Typical morph (male)-Szczecin.

extracted from the claw muscle tissue using the Chelex method (Casquet et al., 2012). The polymerase chain reaction (PCR) followed the protocol provided by Hou et al. (2007). The primer pair HCOJJ/LCOJJ (Astrin and Stuben, 2008) was adapted. PCR products were purified with Exonuclease I and FastAP alkaline phosphatase (Werle et al., 1994). Then they were sent for sequencing in Macrogen Inc., Korea. Obtained sequences were aligned, trimmed to the same length $(627 \mathrm{bp})$ and deposited in the GenBank data base (Benson et al., 2005) with accession numbers, MT103928 and MT103929. COI sequences of $F$. limosus were also acquired from GenBank data base for the comparison. Their accession numbers were obtained as follows: KX417109 (Thoma et al., 2016) and DQ882096 (Costa et al., 2007). The phylogenetic tree was built with Maximum Likelihood method using MEGA 7.0 (Kumar et al., 2016). As an outgroups the sequences of Faxonius rusticus, deposited in GenBank by Kessler et al. (2015) with the accession number KT282409, as well as Faxonius barrenensis, deposited in GenBank (accession number MG872956) by Fetzner and Taylor (2018), were used. Haplotypes were checked in DnaSP software (Librado and Rozas, 2009).

For qualitative assessment of the pigmentation confirming mutation in astaxanthin-based pigment complexes or possible difference in pigment quantity, separate pereiopod samples were taken. Samples were placed in ethyl alcohol as well as in boiling water for an observation. In result protein denaturation was observed. Control sample contained pereiopods typically coloured. In both cases, the leg samples taken after placing in boiling water turned orange-red, however much less intense than in the individuals with the original colouration.

Collected specimens were identified as representatives of F. limosus. Taxonomic affiliation to the species was confirmed by the DNA Standard Barcoding procedure study. Moreover, all the studied individuals represented only one haplotype (both blue specimens as well as the sequences taken from

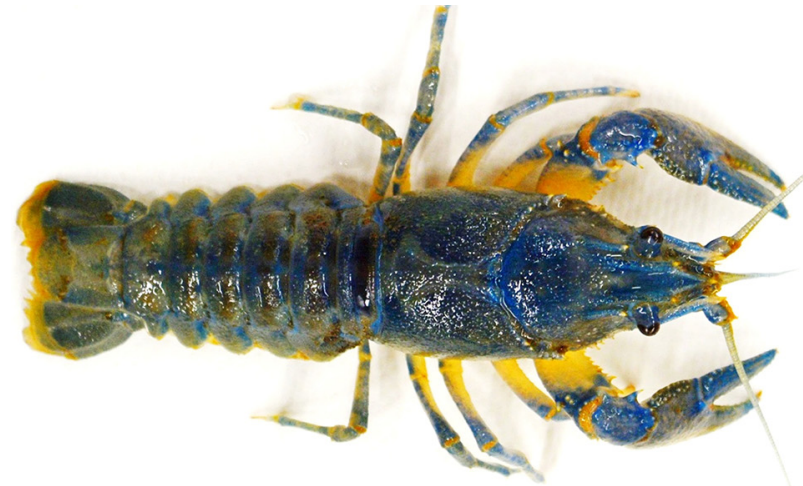

A

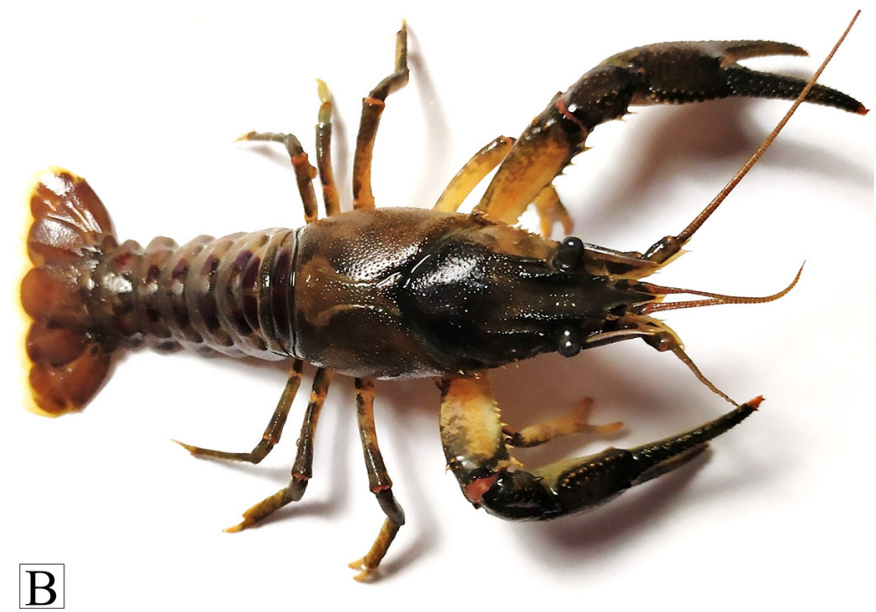

Fig. 3. Neighbour-Joining tree for blue Faxonius limosus and GenBank-stored sequences.

GenBank collection) (Fig. 3). Individual from Szczecin was identified as female, while the one from Kielce, was a male. Crayfish were characterised by total length of 97 and $40 \mathrm{~mm}$ respectively. Differences in the coloration of the blue individual and the typical coloration of the crayfish are shown in Figure 2.

Collected individuals are the first records of blue colour forms of the F. limosus, although such colouration has already been reported in other species within the Cambaridae family (Fitzpatrick, 1987; Secker, 2013), as well as in the genus Faxonius (Momot and Gall, 1971; Thacker et al., 1993). Despite the small sample, it can be estimated that blue pigmentation may occur in males and females as representatives of both sexes were caught and it is possible to recognize it already in non-reproductive phase as one of the specimens shown the characteristics typical for form II (Berrill and Arsenault, 1984; Chybowski and Juchno, 2002). Obtained results suggest that blue-coloured crayfish occur in no more than $0.5 \%$ of the population of this species $(1 / 180$ and $1 / 200)$ which is similar to what was stated by Momot and Gall (1971) in other species of the genus Faxonius.

Blue colouration is most probably genetic-based as it was already suggested by e.g. Dowell and Winier (1969), as well as Momot and Gall (1971). However, environmental factors should be also considered (Bowman, 1942; Kaldre et al., 2015; Fingerman, 2016). The basis of crayfish colouration are 
pigment-protein complexes in which the colouring agents are most often astaxanthin containing compounds (HigueraCiapara et al., 2006). Temporary blue colouration is often observed in aquarium crustaceans, including the Cambaridae family (Umbers et al., 2014; Kaldre et al., 2015) and may occur due to a change in dispersion of pigment grain in chromatophores. In this case, the concentration of the exemplary black colorant in the cell gives the visual effect of blue glow, while its dispersion presents black colour. Most often it occurs in response to stress caused by transport, change in environmental conditions (including physical and chemical parameters e.g. such as the light and background) and may be food dependent (Thacker et al., 1993; Kaldre et al., 2015; Fingerman, 2016). In the latter case, astaxanthin deficiency may give the effect of blue coloured individuals, as demonstrated by Kaldre et al. (2015). This is probably due to the impossibility of forming astaxanthin-protein complexes. In result the chromatophores contain less pigment grains, which, regardless of dispersion, is responsible for the visual effect of blue colouration (free spaces between existing pigment grains). However, this is a temporary condition that may change when astaxanthin enriched food is provided. Similar, but long-lasting effect can be obtained by selection, therefore, on the basis of genetic factors. In this case, regardless of the amount of astaxanthin provided in food, the colour remains blue (Fingerman, 2016). This conclusion is supported by the invariability of the colouration of the collected blue $F$. limosus, despite providing rich in astaxanthin food servings, as well as by bigger number of standard coloured individuals present in the same environmental conditions (Secker, 2013). However, as only 2 specimens were observed, more detailed investigations should be conducted comparing histological and molecular methods. The argument supporting this hypothesis will be also, the less intense red colouration of the sampled pereiopod fragments of crayfish with blue and standard colouration. Paler colouration is most likely the result of a lower content of astaxanthincontaining compounds (Parisenti et al., 2011). The above conclusions require confirmation by performing additional research focused on determining the exact biochemical changes of carotenoproteins and taking into account the genetic basis of these changes.

Presence of new colouration in F. limosus followed by the lack of distinctive dark red bands on the abdomen terga may cause misidentification, especially in species native to Europe and associated with blue colour variety such as in the Astacidae family (Rivas et al., 1988).

It could result in misidentification of individuals being released into natural environment. However, in Europe, blue colour may also occur in alien crayfish such as Pacifastacus leniusculus (Dana, 1852) (Fitzpatrick, 1987), as well as in other representatives of the Cambaridae family, including the aquarium forms of Procambarus clarkii, which have already been recorded in Polish inland waters (Maciaszek et al., 2019).

We recommend introducing to the crayfish identification keys a possibility of occurrence of blue colouration in F. limosus which may disrupt classification due to undetermined taxonomical features. Although atypical individuals are observed very rarely, information regarding potential occurrence of other colouration should be provided to enable public to comply effectively with the law. It is also recommended to emphasize that the identification of the crayfish should not be solely based on its colouration.

Acknowledgments. We thank Wiktor Liwoch for his valuable help in collecting crayfish.

\section{References}

Astrin JJ, Stuben PE. 2008. Phylogeny in cryptic weevils: molecules, morphology and new genera of western Palaearctic Cryptorhynchinae (Coleoptera: Curculionidae). Invertebr Syst 22: 503-522.

Benson DA, Karsch-Mizrachi I, Lipman DJ, Ostell J, Wheeler DL. 2005. GenBank. Nucl Acids Res 33: D34-38.

Berrill M, Arsenault M. 1984. The breeding behaviour of a northern temperate orconectid crayfish, Orconectes rusticus. Anim Behav 32: 333-339.

Bowman TE. 1942. Morphological color change in the crayfish. Am Nat 76: 332-336.

Casquet J, Thebaud C, Gillespie RG. 2012. Chelex without boiling, a rapid andeasy technique to obtain stable amplifiable DNA from small amounts of ethanol-stored spiders. Mol Ecol Resour 12: 136-41.

Chucholl C. 2013. Invaders for sale: trade and determinants of introduction of ornamental freshwater crayfish. Biol Invasions 15: 125-141.

Chucholl C, Wendler F. 2017. Positive selection of beautiful invaders: long-term persistence and bio-invasion risk of freshwater crayfish in the pet trade. Biol Invasions 19: 197-208.

Chybowski L, Juchno D. 2002. Histological analysis of the annual cycle of gonad development in the male spiny cheek crayfish Orconectes limosus. Raf Arch Pol Fish 10: 241-253.

Costa P, deWaard JR, Boutillier J, Ratnasingham S, Dooh RT, Hajibabaei M, Hebert PDN. 2007. Biological identifications through DNA barcodes: the case of the Crustacea. Can J Fish Aquat Sci 64: 272-295.

Crandall KA, De Grave S. 2017. An updated classification of the freshwater crayfishes (Decapoda: Astacidea) of the world, with a complete species list. J Crustacean Biol 37: 615-653.

Dowell VE, Winier LP. 1969. A bilateral color anomaly in the crayfish, Orconectes immunis (Hagen). Proc Iowa Acad Sci 76: 487-492.

Fetzner JWJ, Taylor CA. 2018. Two new species of freshwater crayfish of the genus Faxonius (Decapoda: Cambaridae) from the Ozark Highlands of Arkansas and Missouri. Zootaxa 4399: 491-520.

Filipová L, Lieb DA, Grandjean F, Petrusek A. 2011. Haplotype variation in the spiny-cheek crayfish Orconectes limosus: colonization of Europe and genetic diversity of native stocks. $J$ North Am Benthol Soc 30: 871-881.

Fingerman M. 2016. The control of chromatophores: international series of monographs on pure and applied biology. Elsevier, pp. 7-14.

Fitzpatrick JF. 1987. Notes on the so-called "blue color phase" in North American cambarid crawfishes (Decapoda, Astacoidea). Crustaceana 52: 316-9.

Füreder L, Machino Y. 2002. A revised determination key of freshwater crayfish in Europe. Ber Naturwiss-med Ver Innsb 89: $169-178$.

Higuera-Ciapara I, Felix-Valenzuela L, Goycoolea FM. 2006. Astaxanthin: a review of its chemistry and applications. Crit Rev Food Sci Nutr 46: 185-196.

Holdich DM. 1993. A review of astaciculture: freshwater crayfish farming. Aquat Living Resour 6: 307-317. 
Hou Z, Fu J, Li S. 2007. A molecular phylogeny of the genus Gammarus (Crustacea: Amphipoda) based on mitochondrial and nuclear gene sequences. Mol Phylogenet Evol 2: 596-611.

Kaldre K, Haugjärv K, Liiva M, Gross R. 2015. The effect of two different feeds on growth, carapace colour, maturation and mortality in marbled crayfish (Procambarus fallax f. virginalis). Aquac Int 23: 185-194.

Kessler IVRA, Black TR, Fraley SJ, Gangloff MM. 2015. Molecular and morphological analyses reveal cryptic crayfish invasions in the Appalachian Mountains. Freshw Crayfish 21: 51-62.

Kouba A, Petrusek A, Kozák P. 2014. Continental-wide distribution of crayfish species in Europe: update and maps. Knowl Manag Aquat Ecosyst 413: 5.

Krzywosz T. 1999. Astakofauna Polski: historia, stan obecny, perspektywy. Olsztyn: Wydawnictwo IRŚ, pp. 467-482.

Kumar S, Stecher G, Tamura K. 2016. MEGA 7: Molecular evolutionary genetics analysis Version 7.0 for bigger datasets. Mol Biol Evol 33: 1870-1874.

Librado P, Rozas J. 2009. DnaSP v5: a software for comprehensive analysis of DNA polymorphism data. Bioinformatics 25: 1451-1452.

Maciaszek R, Bonk M, Strużyński W. 2019. New records of the invasive red swamp crayfish Procambarus clarkii (Girard, 1852) (Decapoda: Cambaridae) from Poland. Knowl Manag Aquat Ecosyst 420: 39.

Manenti R, Ghia D, Fea G, Ficetola GF, Padoa-Schioppa E, Canedoli C. 2019. Causes and consequences of crayfish extinction: Stream connectivity, habitat changes, alien species and ecosystem services. Freshw Biol 64: 284-293.

Momot WT, Gall JE. 1971. Some ecological notes on the blue color phase of the crayfish, Orconectes virilis, in two lakes. Ohio J Sci 71: $363-70$.

Nolfi JR. 1980. Commercial aquaculture systems for crawfish in the northeastern United States. Proc World Maricul Soc 11: 151-162.

Oficialdegui FJ, Clavero M, Sánchez MI, et al. 2019. Unravelling the global invasion routes of a worldwide invader, the red swamp crayfish (Procambarus clarkii). Freshw Biol 64: 1382-1400.

Parisenti J, Beirão LH, Tramonte VL, Ourique F, da Silveira Brito CC, Moreira CC. 2011. Preference ranking of colour in raw and cooked shrimps. Int J Food Sci Technol 46: 2558-2561.

Pârvulescu L, Palos C, Molnar P. 2009. First record of the spiny-cheek crayfish Orconectes limosus (Rafinesque, 1817)(Crustacea: Decapoda: Cambaridae) in Romania. North West J Zool 5: 424-428.

Patoka J, Petrtýl M, Kalous L. 2014. Garden ponds as potential introduction pathway of ornamental crayfish. Knowl Manag Aquat Ecosyst 414: 13.
Rivas JD, Milicua JCG, Gomez R. 1988. Further studies on the blue carotenoprotein from Astacus leptodactylus. Comp Biochem 89: $65-68$.

Secker HL. 2013. Evidence of blue coloration in a population of Prairie crayfish (Procambarus gracilis (Bundy, 1876) (Decapoda, Cambaridae)) in northeastern Illinois, USA. Crustaceana 86: 313-321.

Seprös R, Farkas A, Sebestyén A, et al. 2018. Current status and distribution of non-native spiny cheek crayfish (Faxonius limosus Rafinesque, 1817) in Lake Balaton. Hung Agric Res 27: 20-26.

Śmietana P, Bonk M, Solarz W. 2018. Orconectes limosus (Rafinesque, 1817)-Karta informacyjna gatunku. Source: Generalna Dyrekcja Ochrony Środowiska. www.projekty.gdos.gov.pl/ igo [Accessed 2/14/2020].

Souty-Grosset C, Holdich D, Noel P, Reynolds JD, Haffner P. 2006. Atlas of crayfish in Europe. Muséum national d'Histoire naturelle, Paris (Patrimoines naturels 64), $187 \mathrm{p}$.

Souty-Grosset C, Anastácio PM, Aquiloni L, et al. 2016. The red swamp crayfish Procambarus clarkii in Europe: impacts on aquatic ecosystems and human well-being. Limnologica 58: 78-93.

Stanek M, Kupcewicz B, Dąbrowski J, Janicki B. 2010. Estimation of fat content and fatty acids profile in the meat of spinycheek crayfish (Orconectes limosus Raf.) from the Brda river and the lake Gopło. $J$ Cent Eur Agric 11: 297-304.

Svecker CD, Jones TD, Kilian JV, Roverson L. 2019. Key to the Crayfish of Maryland. Maryland: Maryland Department of Natural Resources, pp. 26-35.

Svoboda J, Mrugała A, Kozubíková-Balcarová E, Petrusek A. 2017. Hosts and transmission of the crayfish plague pathogen Aphanomyces astaci: a review. J Fish Diseases 40: 127-140.

Thacker RW, Hazlett BA, Esman LA, Stafford CP, Keller T. 1993. Color morphs of the crayfish Orconectes virilis. Am Midl Nat 129: 182-199.

Thoma RF, Fetzner Jr. JW, Whitney Stocker G, Loughman ZJ. 2016. Cambarus (Jugicambarus) adustus, a new species of crayfish from northeastern Kentucky delimited from the Cambarus (J.) aff. dubius species complex. Zootaxa 4162: 173-187.

Umbers KD, Fabricant SA, Gawryszewski FM, Seago AE, Herberstein ME. 2014. Reversible colour change in Arthropoda. Biol Rev 89: 820-848.

Werle E, Schneider C, Renner M, Völker M, Fiehn W. 1994. Convenient single-step, one tube purification of PCR products for direct sequencing. Nucl Acids Res 22: 4354-4355.

Cite this article as: Maciaszek R, Bonk M, Sosnowski W, Jabłońska A. 2020. First record and DNA barcodes of the invasive blue-coloured spiny-cheek crayfish Faxonius limosus (Rafinesque, 1817) (Decapoda: Cambaridae). Knowl. Manag. Aquat. Ecosyst., $421,20$. 